\title{
Role of Vena Cava Inferior Filter on Neurosurgical Deep Venous Thrombosis
}

\author{
Nöroşirürjikal Derin Ven Trombozunda Vena Cava Inferior Filtresinin \\ Rolii
}

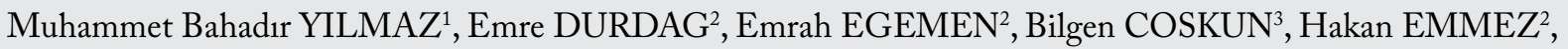
Gokhan KURT ${ }^{2}$, Erhan ILGIT ${ }^{3}$

${ }^{1}$ M. H. Training and Research Hospital, Department of Neurosurgery, Kayseri, Turkey

${ }^{2}$ Gazi University, Faculty of Medicine, Department of Neurosurgery, Ankara, Turkey

${ }^{3}$ Gazi University, Faculty of Medicine, Department of Radiology, Ankara, Turkey

Correspondence address: Muhammet Bahadır YILMAZ / E-mail: mbahadiryilmaz@yahoo.com.tr

\begin{abstract}
AIM: The patients who undergo neurosurgical procedures are at high risk for perioperative deep vein thrombosis and pulmonary embolism. Pharmacological prophylaxis with mechanic prophylaxis is a safe and effective way of preventing deep vein thrombosis and pulmonary thromboembolism in neurosurgery. However, pharmacological prophylaxis may increase the risk of hemorrhage after cranial or spinal operations.

MATERIAL and METHODS: Patients with vena cava inferior filter were retrospectively examined between 2003 and 2010.

RESULTS: Approximately 1600 patients per year are operated in our clinic. Deep vein thrombosis incidence is \% $1.2-2.3$ in our department. Vena cava inferior filter is used on 13 patients who operated for various diagnoses, during the $2003-2010$ period. None of these patients had new pulmonary thromboembolism after inserting vena cava inferior filter but two of them died cause of initial respiratory distress.

CONCLUSION: We think that vena cava inferior filter in is safe and effective method for pulmonary thromboembolism prophylaxis, especially for patients with high bleeding risk and who cannot be anticoagulated. Further prospective studies with larger series are needed for evaluating long term complications and benefits.
\end{abstract}

KEYWORDS: Vena cava inferior filter, Pulmoner thromboembolism, Deep venous thrombosis, Anticoagulation, Prophylaxis

\section{öz}

AMAÇ: Nöroşirürjikal prosedür uygulanan hastalar perioperatif derin ven trombozu ve pulmoner emboli için yüksek risklidir. Mekanik profilaksi ile farmakolojik profilaksi, nöroşirürjide derin ven trombozu ve pulmoner emboliyi önlemenin güvenilir ve etkili yoludur. Bununla birlikte, farmakolojik profilaksi kranial ve spinal operasyonlar sonrası hemoraji riskini artırabilir.

YÖNTEM ve GEREÇLER: 2003-2010 yılları arasındaki vena kava inferior filtreli hastalar retrospektif incelendi.

BULGULAR: Kliniğimizde yılda yaklaşık 1600 hasta opere edilmektedir. Bölümümüzde derin ven trombozu insidansı \%1.2-2.3 arasındadır. 2003-2010 yılları arasında çeşitli tanıları olan 13 hastada vena kava inferior filtresi kullanıldı. Bu hastaların hiçbirinde vena kava inferior filtresi takıldıktan sonra yeni pulmoner tromboemboli gelişmedi fakat ikisi önceki solunum sıkıntısı nedeniyle öldü.

SONUÇ: Biz, özellikle kanama riski yüksek ve antikoagüle edilemeyen hastalarda pulmoner tromboemboli profilaksisi için vena kava inferior filtresinin güvenli ve etkili metod olduğunu düşünüyoruz. Uzun vadeli komplikasyon ve yararların değerlendirilmesi için daha fazla büyük serili prospektif çalışmaya ihtiyaç vardır.

ANAHTAR SÖZCÜKLER: Vena kava inferior filtresi, Pulmoner tromboemboli, Derin ven trombozu, Antikoagülasyon, Profilaksi

\section{INTRODUCTION}

Venous thromboembolism (VTE) refers to both deep vein thrombosis (DVT) and pulmonary thromboembolism (PE) (16) DVT and PE are significant causes of morbidity and mortality following surgery. The incidence of DVT and PE show big differences due to treatments in a review of the literature. VTE occurs in more than 200,000 people per year in the United States (25). The authors also described the incidence of symptomatic VTE as $3-6 \%$, PE as $1.5-5 \%$ and mortality as $9-50 \%$ (27). The patients who undergo neurosurgical procedures are at high risk for perioperative DVT and PE, which have been reported in $6 \%$ to $43 \%$ of these patients (6). The strong relationship between VTE and PE also requires an effective prophylaxis in neurosurgery patients. The complication of hemorrhage at the early post-operative period increases the importance of a prophylaxis regimen for VTE in neurosurgery patients. Mechanical prophylaxis with elastic bandages and intermittent pneumatic compression (IPC) reduce risk for neurosurgery patients and are known to 
be adequate for prophylaxis. In recent series, authors suggest that low doses of subcutaneous (sc) unfractionated heparin or low-molecular-weight heparin (LMWH) increase the efficiency of prophylaxis (6). Nonetheless, prophylaxis with LMWH may increase the risk of hemorrhage after cranial or spinal operations. This issue has recently made the vena cava filter more popular.

\section{MATERIAL and METHODS}

Patients with VCF were retrospectively examined between 2003 and 2010 on single institution (Gazi University Faculty of Medicine, Department of Neurosurgery). VCF was used on 13 patients who were operated for various diagnoses between 2003 and 2010. Age, gender, primary neurosurgical diagnosis, neurological examinations, primary treatment of the situation, DVT prophylaxis, indication and the day of insertion of VCF, and the result of this intervention are noted.

\section{RESULTS}

We prefer mechanical prophylaxis and early mobilization for prevention of DVT in our clinic. DVT can occur despite prophylaxis. We would then rather use pharmacological thromboprophylaxis if the bleeding risk is low and radiological examinations show no bleeding sign. High bleeding risk and contraindications of pharmacologic treatment are indications to use VCF. Among the 1600 operated patients in our department per year, the DVT incidence is $1.2-2.3 \%$. Distribution of gender is 9 male patients to 4 female ones. Ages are between 31 and 81 and the average is 56.2 years.

Two of these patients were diagnosed with DVT and PE with respiratory failure on the postoperative $16^{\text {th }}$ and $49^{\text {th }}$ days. One patient has PE and DVT on the $3^{\text {th }}$ day post-operatively. None of these patients had new PE after inserting VCF but two of them died because of the initial respiratory distress. All of the patients had used mechanical prophylaxis and suitable patients were mobilized early. Three of the patients operated on for intracranial mass had DVT under pharmacological thromboprophylaxis. Ten of those patients had neurological deficits preventing ambulation. The details of the patients with DVT and PE are shown in Table I.

\section{DISCUSSION}

Three mechanisms known as Virchow's Triad are involved in the pathogenesis of DVT $(5,20)$. These are hypercoagulable states, venous stasis and injury of the venous wall. The risk factors which can contribute to DVT are often present in neurosurgical patients. Older age, malignancies, cranial or spinal injury, obesity, heart failure, myocardial infarction, hypercoagulable states, extensive surgery, previous venous thrombosis, paresis and immobility, oral contraceptives are well-known predisposing factors for DVT $(6,20,24,26)$. Nonetheless the brain contains a great amount of tissue thromboplastin (13). Thromboplastin secretion is maximum during intracranial surgery, in infarction and trauma $(13,21)$. DVT is the most frequent complication following craniotomy for brain tumors $(10,13)$. Many neoplastic diseases like malignant glioma and meningioma predispose to formation of DVT because of having some intrinsic factors (13). Patients with malignant glioma require an effective prophylaxis strategy (13). DVT risk increases day by day in case of absence of prophylaxis. Because of the mentioned factors, DVT prophylaxis is important in neurosurgery. PE is the most important and fatal complication of DVT. PE incidence due to DVT could be reduced with a treatment modality.

The authors aimed to analyze the effectiveness and safety of prophylaxis protocols in neurosurgical patients. The authors also aimed to analyze the risk factors of DVT which are only related to neurosurgical disorders. In the analysis of spinal operations, no significant difference was found between patients with spinal tumor, trauma and disc herniation or degenerative spinal diseases. The review of cranial operations also showed no significant difference between neurovascular diseases and intracranial hemorrhages, head trauma, tumor or other diseases. The pitfall of these findings is that, this analysis was done regardless of the sex, age, paresis, immobility period. A more detailed analysis including the listed features may provide different results.

The incidence of DVT shows big differences due to the treatment in the review of the literature. The authors also described the incidence of symptomatic VTE as 3-6\%, PE as $1.5-5 \%$ and mortality as $9-50 \%$ (27). The patients who undergo neurosurgical procedures are at high risk for perioperative DVT and PE, which have been reported in $6 \%$ to $43 \%$ of those patients. Flinn et al. (6) demonstrated that DVT incidence is $7.7 \%$ in cranial operations and $1.5 \%$ in spinal operations. Black et al. (3) found the incidence of DVT as 29 to $43 \%$ for the patients who underwent combined cranial and spinal surgery with no prophylaxis (6). DVT risk is higher in spinal injury. Audibert et al. (1) described DVT incidence as $81 \%$ using venography without prophylaxis and the risk of symptomatic DVT was 12 to $23 \%$. The risk is much lower in elective spine surgery. The risk of DVT is less than $1 \%$ after discectomy or laminectomy on less than two spine levels (1). In the presented study, no significant difference was detected between spinal and cranial surgery as a risk factor for DVT.

Pneumatic compression of the legs enhances fibrinolysis by reducing the level of plasminogen activator inhibitor and increasing the level of circulating endogenous tissue plasminogen activator (4). Elastic bandages and IPC have minimal risk for neurosurgery patients and are adequate for prophylaxis but additional low dose unfractionated heparin (LMWH) therapy provide much more efficient treatment (6). In a study involving 523 patients, DVT incidence was described as $2.3 \%$ with only prophylaxis of IPC and the risk of PE was described as $1.8 \%$ (3). Gnanalingham et al. (9) found that the risk of DVT decreases $79 \%$ with elastic bandages and $90 \%$ with LMWH while the risk of PE decrease $43 \%$ with elastic bandages and $67 \%$ with LMWH treatment. Frim et al. (7) demonstrated that DVT incidence is $3.2 \%$ and PE incidence $3.5 \%$ with only IPC prophylaxis in their series of $611 \mathrm{cranial}$ and spinal cases. They found these incidences as $0 \%$ with combined 
Table I: The Details of Patients with DVT and PE

\begin{tabular}{|c|c|c|c|c|c|c|c|c|}
\hline No & Age & Gender & $\begin{array}{l}\text { Neurosurgical } \\
\text { Diagnosis }\end{array}$ & $\begin{array}{l}\text { Neurological } \\
\text { Examination }\end{array}$ & $\begin{array}{l}\text { Primary } \\
\text { Treatment }\end{array}$ & DVT Prophylaxis & $\begin{array}{l}\text { Indication } \\
\text { and day of } \\
\text { insertion }\end{array}$ & Result \\
\hline 1 & 56 & M & $\begin{array}{l}\text { Traumatic } \\
\text { syringomyelia }\end{array}$ & Quadriparesia & $\begin{array}{l}\text { Syringo- } \\
\text { subdurally } \\
\text { shunting }\end{array}$ & $\begin{array}{l}\text { Mechanical } \\
\text { prophylaxis }\end{array}$ & $\begin{array}{l}\text { Post-op } 15^{\text {th }} \\
\text { day }\end{array}$ & No PE \\
\hline 2 & 59 & $\mathrm{~F}$ & $\begin{array}{l}\text { SAH from anterior } \\
\text { cerebral artery } \\
\text { aneurysm }\end{array}$ & No ND & Embolization & $\begin{array}{l}\text { Mechanical } \\
\text { prophylaxis and } \\
\text { early mobilization }\end{array}$ & $\begin{array}{l}\text { Post-op } 12^{\text {th }} \\
\text { day }\end{array}$ & No PE \\
\hline 3 & 75 & M & $\begin{array}{l}\text { LMWH (low- } \\
\text { molecular-weight } \\
\text { heparin) treatment } \\
\text { for DVT } \\
\text { Temporal-parietal } \\
\text { hypertensive } \\
\text { hematoma }\end{array}$ & Hemiparesia & $\begin{array}{l}\text { Hematoma } \\
\text { evacuation }\end{array}$ & $\begin{array}{l}\text { Mechanical } \\
\text { prophylaxis }\end{array}$ & $\begin{array}{l}\text { Re-dvt on } \\
19^{\text {th }} \text { day and } \\
\text { VCF inserted }\end{array}$ & No PE \\
\hline 4 & 49 & M & Avm and hematoma & Hemiplegia & $\begin{array}{l}\text { Hematoma } \\
\text { evacuation and } \\
\text { avm excision }\end{array}$ & $\begin{array}{l}\text { Mechanical } \\
\text { prophylaxis }\end{array}$ & $\begin{array}{l}\text { Post-op } 14^{\text {th }} \\
\text { day }\end{array}$ & No PE \\
\hline 5 & 38 & M & $\begin{array}{l}\text { Hypertensive basal } \\
\text { ganglia hematoma }\end{array}$ & No ND & Conservative & $\begin{array}{l}\text { Mechanical } \\
\text { prophylaxis and } \\
\text { early mobilization }\end{array}$ & $\begin{array}{l}\text { Dvt on } 15^{\text {th }} \\
\text { day and vcf } \\
\text { inserted }\end{array}$ & No PE \\
\hline 6 & 55 & $\mathrm{~F}$ & $\begin{array}{l}\text { Giant CPA mass } \\
\text { and acute } \\
\text { hydrocephalus }\end{array}$ & $\begin{array}{l}\text { Glasgow coma } \\
\text { scale (GCS):8 } \\
\text { Post-op GCS:9 }\end{array}$ & $\begin{array}{l}\text { V-p shunting } \\
\text { and } \\
\text { decompressive } \\
\text { surgery for } \\
\text { tumor }\end{array}$ & $\begin{array}{l}\text { Mechanical } \\
\text { prophylaxis and } \\
\text { clexane } 2 \times 0,6 \mathrm{cc} \\
\text { one week after }\end{array}$ & $\begin{array}{l}\text { Post-op } 15^{\text {th }} \\
\text { day }\end{array}$ & $\begin{array}{l}\text { No PE, } \\
\text { exitus from } \\
\text { neurosurgical } \\
\text { complications }\end{array}$ \\
\hline 7 & 70 & M & $\begin{array}{l}\text { Giant CPA mass } \\
\text { and acute } \\
\text { hydrocephalus }\end{array}$ & $\begin{array}{l}\text { GCS:7 } \\
\text { Post-op GKS:7 }\end{array}$ & $\begin{array}{l}\text { V-p shunting } \\
\text { and } \\
\text { decompressive } \\
\text { surgery for } \\
\text { tumor }\end{array}$ & $\begin{array}{l}\text { Mechanical } \\
\text { prophylaxis and } \\
\text { clexane } 2 \text { x0,6 cc } \\
\text { one week after }\end{array}$ & $\begin{array}{l}\text { Post-op } 18^{\text {th }} \\
\text { day }\end{array}$ & $\begin{array}{l}\text { No PE, } \\
\text { exitus from } \\
\text { neurosurgical } \\
\text { complications }\end{array}$ \\
\hline 8 & 81 & M & Meningioma & Hemiparesis & Excision & $\begin{array}{l}\text { Mechanical } \\
\text { prophylaxis and } \\
\text { early mobilization }\end{array}$ & $\begin{array}{l}\text { Post-op } 11^{\text {th }} \\
\text { day }\end{array}$ & No PE \\
\hline 9 & 61 & M & $\begin{array}{l}\text { Cerebellar } \\
\text { metastasis of malign } \\
\text { melanoma }\end{array}$ & No ND & Excision & $\begin{array}{l}\text { Mechanical } \\
\text { prophylaxis and } \\
\text { early mobilization }\end{array}$ & $\begin{array}{l}\text { DVT and } \\
\text { PE on } 49^{\text {th }} \\
\text { day and vcf } \\
\text { inserted }\end{array}$ & No new PE \\
\hline 10 & 60 & M & Sarcoma metastasis & $\begin{array}{l}\text { hemiplegia, } \\
\text { GCS:10 }\end{array}$ & Excision & $\begin{array}{l}\text { Mechanical } \\
\text { prophylaxis }\end{array}$ & $\begin{array}{l}\text { Post-op } 9^{\text {th }} \\
\text { day }\end{array}$ & No PE \\
\hline 11 & 31 & $\mathrm{~F}$ & $\begin{array}{l}\text { GBM and } \\
\text { hematoma }\end{array}$ & $\begin{array}{l}\text { Lethargy, } \\
\text { hemiplegia }\end{array}$ & $\begin{array}{l}\text { Excision of } \\
\text { tumor and } \\
\text { evacuation }\end{array}$ & $\begin{array}{l}\text { Mechanical } \\
\text { prophylaxis }\end{array}$ & $\begin{array}{l}\text { Post-op } 3^{\text {rd }} \\
\text { day }\end{array}$ & $\begin{array}{l}\text { No PE after } \\
\text { filter. Died } \\
\text { because of } \\
\text { pulmonary } \\
\text { distress }\end{array}$ \\
\hline 12 & 43 & $\mathrm{~F}$ & Giant meningioma & Hemiparesis & Excision & $\begin{array}{l}\text { Mechanical } \\
\text { prophylaxis and } \\
\text { clexane } 2 \text { × } 0.41 \\
\text { week after }\end{array}$ & $\begin{array}{l}\text { Post-op } 24^{\text {th }} \\
\text { day }\end{array}$ & No PE \\
\hline 13 & 53 & M & Metastatic tumor & NO ND & Excision & $\begin{array}{l}\text { Mechanical } \\
\text { prophylaxis and } \\
\text { early mobilization }\end{array}$ & $\begin{array}{l}\text { Post-op } 16^{\text {th }} \\
\text { day }\end{array}$ & Exitus from $\mathrm{PE}$ \\
\hline
\end{tabular}


therapy of IPC and low dose unfractionated heparin in their study involving 138 patients (7). Adding LMWH therefore provides more effective prophylaxis for DVT but the risk of hemorrhage should be kept in mind. In the literature, the risk of haemorrhage is reported as 2 to $4 \%$ in cranial series and $0.7 \%$ in spinal series. The incidence of minor haemorrhage is $3.4 \%$ and the incidence of major haemorrhage is $3.4 \%(2,6,25)$. Gerlach et al. (8) investigated the risk of haemorrhage in 1954 patients who had IPC and nadroparin (Fraxiparine 0.3 milliliter / $2850 \mathrm{U}$ ) administered and found the DVT rate to be $0.7 \%$ and the incidence of haemorrhage to be $0.7 \%$.

VCF became so popular by preventing serious mortality and morbidity of PE after DVT. It is important in patients with a high risk of bleeding that create a contraindication for the use of anticoagulants. Insertion of VCF lowers the risk of symptomatic and recurrent PE. Complications of the intervention are injury to the vena cava, thrombosis of the vena cava, slipping of the filter, thrombosis of the renal vein, and chronic venous insufficiency. However, cumulative experiences and newly designed filters mostly overcome these complications $(11,16,19,22,23,25)$.

Patients with aneurysmal subarachnoid haemorrhage are classified as having moderate risk (10-40 \%) for DVT $(13,28)$. Although mechanical techniques provide adequate prophylaxis for most of these patients, VTE may still occur (28). Inferior vena caval filters provide an alternative to full anticoagulation in patients with aneurysmal subarachnoid haemorrhage at highest risk of catastrophic complications (28).

The timing of anticoagulation therapy for VTE treatment or prophylaxis after intracranial surgery is controversial. The common opinion is that initiation of anticoagulation treatment 3-7 days after neurosurgical approaches is safe enough $(13,15,28)$.

\section{CONCLUSIONS}

Pharmacological prophylaxis with mechanical prophylaxis is a safe and more effective way of preventing deep vein thrombosis in neurosurgery. The risk of deep vein thrombosis is nearly the same in spinal and cranial surgery. We think that VCF in is a safe and effective method for PE prophylaxis, especially for patients with high bleeding risk who cannot be anticoagulated. Further prospective studies with larger series are needed for evaluating long term complications and benefits.

\section{REFERENCES}

1. Audibert G, Faillot T, Vergnes MC, Bosson JL, Bernard C, Payen JF, Lestienne B, Bruder N: Thromboprophylaxis in elective spinal surgery and spinal cord injury. Ann Fr Anesth Reanim 24:928-934, 2005

2. Auguste KI, Quinones-Hinojosa A, Gadkary C,Zada G, Lamborn KR, Berger MS: Incidence of venous thromboembolism in patients undergoing craniotomy and motor mapping for glioma without intraoperative mechanical prophylaxis to the contralateral leg. J Neurosurg 99:680 -684, 2003
3. Black PM, Baker MF, Snook CP: Experience with external pneumatic calf compression in neurology and neurosurgery. Neurosurgery 18:440 - 444,1986

4. Comerota AJ, Chouhan V, Harada RN, Sun L, Hosking J, Veermansunemi R, Comerota AJ Jr, Schlappy D, Rao AK: The fibrinolytic effects of intermittent pneumatic compression: Mechanism of enhanced fibrinolysis. Ann Surg 226: 306-313,1997

5. Emmerich J: Mechanisms and risk factors of venous thromboembolic disease. Rev Prat 46:1203-1210,1996

6. Flinn WR, Sandager GP, Silva Jr MB, Benjamin ME, Cerullo LJ, Taylor M: Prospective surveillance for perioperative venous thrombosis. Experience in 2643 patients. Arch Surg 131: 472-480,1996

7. Frim DM, Barker II FG, Poletti CE, Hamilton AJ: Postoperatif low dose heparin decreases thromboembolic complications of neurosurgical patients. Neurosurgery 30:830-832,1992

8. Gerlach R, Raabe A, Beck J, Woszczyk A, Seifert V: Postoperatif nadroparin administration for prophylaxis of thromboembolic events is not associated with an increased risk of hemorrhage after spinal surgery. Eur Spine J 13:9-13, 2004

9. Gnanalingham KK, Holland JP: Attitudes to the use of prophylaxis for thromboembolism in neurosurgical patients. J Clin Neurosci 10:467-469, 2003

10. Goldhaber SZ, Dunn K, Gerhard-Herman M, Park JK, Black PM: Low rate of venous thromboembolism after craniotomy for brain tumor using multimodality prophylaxis. Chest 122:1933-1937, 2002

11. Grassi CJ: Inferior ven caval filters; Analysis of five currently available devices. Am J Roentgerol 156:813-821, 1991

12. Haines ST: Venous thromboembolism: Pathophysiology and clinical presentation. Am J Health Syst Pharm 60:3-5, 2003

13. Hamilton MG, Hull RD, Pineo GF:Venous thromboembolism in neurosurgery and neurology patients: A review. Neurosurgery 34:280-296, 1994

14. Imanaka S, Aihara S, Yoshihara K, Kato A, Matsumoto K, Kudo S: Use of a temporary caval filter in a young man with pulmonary embolism to prevent migration of massivecaval thrombus during an attempt of caval thrombolysis. J Atheroscler Thromb 6:18-21, 2000

15. Kawamata T, Takeshita M, Kubo O, Izawa M, Kagawa M, Takakura K: Management of intracranial hemorrhage associated with anticoagulant therapy. Surg Neurol 44:438-443, 1995

16. Khaldi A, Helo N, Schneck MJ, Origitano TC: Venous thromboembolism: Deep venous thrombosis and pulmonary embolism in a neurosurgical population. J Neurosurg 114:40-46, 2011

17. Kim D, Schlam B, Porter DH, Simon M: Insertion of the Simon Nitinol caval filtervalue of the antecubital vein approach. Am J Roentgerol 157:521-522,1991

18. McDonald RL, Amidei C, Baron J, Weir B, Brown F, Erickson RK, Hekmatpanah J, Frim D: Randomized, pilot study of intermittent pneumatic comprssion devices plus deltaparin versus intermittent pneumatic compression devices plus 
heparin for prevention of venous thromboembolism in patients undergoing craniotomy. Surg Neurol 59:363-372, 2003

19. Millward S, Marsh Jl, Peterson R, Rasuli P, French G, Wilson CM, Tennenhouse JE, Morris DC, Simons ME, Formoso AF: LGM (Vena Tech) vena cava filter: Clinical experience in 64 patients. J Vasc Interv Radiol 2:429-433,1991

20. Payen JF, Faillot T, Audibert G, Vergnes MC, Bosson JL, Lestienne B, Bernard C, Bruder N: Thromboprophylaxis in neurosurgery and head trauma. Ann Fr Anesth Reanim 24:921-927, 2005

21. Powers SK, Edwards MS: Prevention and treatment of thromboembolic complications in a neurosurgical patient, in Wilkins RH, Rengachary SS (eds): Neurosurgery. New York: McGraw-Hill, 1985:406-410

22. Ricco JB, Crochet $D$, Sebilotte $P$, Serradimigni A, Lefebvre JM, Bouissou E, Geslin P, Virot P, Vaislic C, Gallet M: Percutaneous transvenous caval interruption with LGM filter. Ann Vasc Surg 2:242-247, 1988
23. Rodriguez JL, Lopez JM, Proctor MC, Conley JL, Gerndt SJ, Marx MV, Taheri PA, Greenfield LJ: Early placement of prophylactic vena caval filters in injured patients at high risk for pulmonary embolism. J Trauma 40:797-802,1996

24. Smith SF, Biggs MT, Sekhon LH: Risk factors and prophylaxis for deep venous thrombosis in neurosurgery. Surg Technol Int 14:69-76, 2005

25. Streiff MB: Vena caval filters: A review for intensive care specialists. J Intensive Care Med 18:59-79, 2003

26. Swann KW, Black PM: Deep vein thrombosis and pulmonary emboli in neurosurgical patients: A review. J Neurosurg 61:1055-1062, 1984

27. Tabori U, Beni-Adani L, Dvir R, Burstein Y, Feldman Z, Pessach I, Rechavi G, Constantini S, Toren A: Risk of venous thromboembolism in pediatric patients with brain tumors. Pediatr Blood Cancer 43:633-636, 2004

28. Wong KC, Boet R, Poon WS, Yu S: Inferior vena caval filters following deep vein thrombosis in patients with ruptured intracranial aneurysm. Hong Kong Med J 8:288-290, 2002 